\title{
THE EFFECT OF DIVERSITY ON TURNOVER: A LARGE CASE STUDY
}

\author{
JONATHAN S. LEONARD and DAVID I. LEVINE*
}

\begin{abstract}
Using longitudinal data collected in 1996-98 from over 800 similar workplaces owned and operated by one corporation, the authors examine how workplace diversity and employee isolation along the dimensions of gender, race, and age affected employee turnover. This design controls for much of the variation in job characteristics and labor markets that have confounded other studies of diversity. The authors use the non-linearity of diversity to distinguish its effect from the main effects of demographic groups and from isolation (being in a numerical minority). The study examines how diversity and isolation by race (white, black, Hispanic, Asian), sex, and age affected different groups. The authors find no consistent evidence that diversity itself increased turnover. In contrast, isolation from coworkers and from customers was often associated with higher turnover.
\end{abstract}

D o differences in demographics within a workgroup, or between a workgroup and its customers, increase employee turnover? Various theories suggest that higher turnover will occur in diverse workplaces, especially among isolated employeesthose whose demographic characteristics put them in the numerical minority in a workplace. A subset of relational theories suggests that the effects of isolation may

*Jonathan Leonard and David Levine are both professors at the Haas School of Business, University of California, Berkeley. They gratefully acknowledge funding from the Center for Organization and $\mathrm{Hu}$ man Resource Effectiveness; the studied employer's generous sharing of data; comments from Jennifer Berdahl, Aparna Joshi, Daniel Levine, Trond Petersen, and seminar participants at Rutgers, Berkeley, Wharton, and the University of Michigan, Ann Arbor; and research assistance from Priyadarshini Kesapragada, Brian Scholl, Bryan Lincoln, and Laura Giuliano. vary according to the race, gender, or age of the demographically isolated employeealthough these theories provide conflicting hypotheses about which groups are most affected by isolation. ${ }^{1}$ A small industry has arisen advising employers how to manage increasingly diverse workplaces, with an emphasis on reducing the friction among demographically diverse workers. However, in spite of the theoretical and practical importance of understanding the conditions under which employees thrive with diverse coworkers, few studies have examined how workplace demographics affect

The data are confidential. For programs, contact either author at Haas School of Business, University of California, Berkeley, \#1900, Berkeley, CA 947201900.

${ }^{1}$ We review these theories of social identity, similarity-attraction, social categorization, historical roles and status, and other variants below.

Industrial and Labor Relations Review, Vol. 59, No. 4 (July 2006). (C) by Cornell University. 0019-7939/00/5904\$01.00 
behavioral outcomes such as employee turnover.

Convincing studies are rare in part because it is challenging to measure the effects of workplace diversity or demographic isolation on employees. The data for this study come from a very large service-sector employer with establishments throughout the United States. ${ }^{2}$ An ideal experiment would (a) have a large number of demographically varied workplaces, so that the effects of multiple measures can be estimated with some precision, (b) control for location to capture differences in the local labor market, the desirability of the workplace's physical location, customer characteristics, and so on (Ashenfelter and Hannan 1986), (c) minimize confounding variation across workplaces in management practices and workplace and job characteristics (such as job content, promotion probabilities, wage levels, selection procedures, and training) that could affect turnover, and (d) randomly assign different demographic mixes to each workplace. Although the employer whose workplaces we study did not randomize demographics, our design is well-suited for the other standards.

We estimate the determinants of individual turnover within workgroups. For testing theories of diversity, our workplaces have enough demographic variation so that we can estimate the nonlinear effect of diversity separately from main effects (such as percent female or white). For testing theories of social roles and status, the data are sufficient to allow estimation of differing effects of diversity and of isolation across demographic groups. Both features of this dataset are rare in the literature.

Our findings are important for understanding theories of demographic similarity (for example, the theory of similarityattraction and Becker's theory of co-em-

\footnotetext{
${ }^{2}$ Due to confidentiality restrictions, we cannot describe the sector of the company or its history in more detail. We will refer to generic "workplaces"for our purposes, outlets performing similar tasks in a chain of retail stores or restaurants.
}

ployee discrimination) and theories of social roles and status.

The considerable amount of rhetoric concerning workplace diversity has not been matched by large-scale studies of workplaces that could provide a factual basis. This study examines the effects of workplace demographic diversity on employee retention: do many employees continue to prefer segregated workplaces four decades after passage of the Civil Rights Act of 1964?

\section{Theory and Past Research}

Theories of diversity in work groups can be divided broadly into two categories with distinct predictions: theories of similarityattraction, which treat each group's role as symmetric, and theories of social roles, according to which groups are differentially affected according to their status rank.

For most Americans, to "increase diversity" means to increase the share of minorities and women in a workplace. This study focuses on the effect of diversity along the dimensions of age, race, ethnicity, and gender. Although many other dimensions might be relevant in the workplace, these dimensions are socially salient, measured in our dataset, and the target of persistent public debate and public policy.

\section{The Effects of Diversity}

Within the social sciences, the ancient insight that "birds of a feather flock together" has developed into a set of theories based on similarity-attraction, social identity, social categorization, and coworker discrimination: people are attracted to those they resemble (Byrne 1971; Tajfel and Turner 1986; Turner 1985; Becker 1957). For example, both blacks and whites prefer a neighborhood in which their own group comprises half or more of the population (Massey and Denton 1993:88-96). If these preferences also hold in workplaces, then exit rates will be lower in homogeneous groups. ${ }^{3}$

${ }^{3}$ The same prediction is made by related theories of organizational demography (Pfeffer 1983) and 
Models of repeated interaction provide economic foundations for these predictions (for example, Greif 1993). If people interact more often with those of their demographic group, both inside and outside the workplace, then we expect more cooperation in demographically similar groups. In addition, many jobs are found through social contacts rather than formal application procedures (Holzer 1988). Demographically similar employees are thus more likely to have overlapping social networks. Reputations for unfriendly actions may be more likely to spread among those sharing a demographic group, and the group can more effectively sanction those who break group norms (Bernstein 1992).

Workplaces also provide various public goods for employees-characteristics of the workplace that affect all employees. These goods range broadly and include minor items such as the choice of how loud to play the workplace's music, subtle norms of attire and language, and investments of time in forming friendships outside the workplace and in helping others at work. If demographic heterogeneity increases the heterogeneity of preferences, then diversity lowers the average satisfaction with any mix of public goods. In general, any taste features that are correlated with demographics are easier to satisfy if demographics are less diverse. This effect can lead to employees sorting themselves into groups with relatively homogeneous preferences (Tiebout 1956). Conversely, lower sorting may reduce some public goods (Alesina et al. 1999). Language is an example of a network externality: commonality is valuable. Diverse groups have more difficulty communicating, and communication difficulties can increase turnover (Price and

social categorization (Tajfel and Turner 1986), and similar predictions come from older theories such as social contact (Allport 1954). Researchers have found attraction based on similarity in characteristics including hobbies, attitudes (Byrne 1971), age, education, religion, health, personality (Boyden et al. 1984), economic status (Byrne et al. 1966; Alesina and La Ferrara 2000), and abilities (Senn 1971).
Mueller 1981). Even among native English speakers, racial diversity (Lang 1986) and gender diversity (Tannen 1990) may make communication difficult.

People may also form an image of the appropriate place for someone like them to work. A proclivity to have a high opinion of oneself and one's demographic group makes it natural to populate this image with similar colleagues. Employees may be less attached to a workplace with a demographic profile different from their own (Tsui et al. 1992:554).

These theories predict that people with similar demographic backgrounds are likely to be more attracted to each other, to trust each other more, to believe they will receive more favorable treatment from each other, and to communicate more easily than would people with dissimilar backgrounds. ${ }^{4}$ These suggest

Hypothesis 1. Turnover is lower in workplaces with low diversity of gender, race, and age.

The young workers in our sample had not yet moved much beyond the confines of their homes, their neighborhoods, and their schools. For all groups, homes are usually racially homogeneous. For neighborhoods and schools, average diversity depends on the group: spending time in racially diverse neighborhoods and schools

${ }^{4}$ The empirical record is scanty and mixed. O'Reilly et al. (1989) found that groups with a high coefficient of variation of tenure were the least socially integrated groups and the most likely to have members exit. These results are difficult to interpret causally, as turnover affects the distribution of tenure by reducing the number of low-tenure employees. Wiersema and Bird (1993) found that within the top management teams of Japanese firms, high team turnover was significantly correlated with heterogeneity on age, on team tenure, and on the prestige of the universities attended. At a much higher level of aggregation, a metropolitan area's diversity in income and race has predicted low scores in self-reports of trusting attitudes (Alesina and La Ferrara 2000). Those articles, like this one, examined only one set of outcomes from diversity. To the extent that demographic diversity increases organizational stakeholders' knowledge, creativity, and diversity of information, it may increase workgroup effectiveness (Jehn, Northcraft, and Neale 1999). 
is common for Asians, fairly common for blacks and Hispanics, and relatively uncommon for whites. For example, in 2000-2001, on average, whites attended high schools with a diversity index of $35 \%$; for black and Hispanic students, diversity was near $60 \%$; and for Asian students, it was $69 \%$ (calculated from Frankenberg, Lee, and Orfield 2003). If this familiarity with diversity creates comfort, then we have

Hypothesis 2a. As racial diversity increases, white turnover will increase faster and Asian turnover will increase more slowly than will black or Hispanic turnover.

Both men and women grow up in gender-mixed settings. Thus, we have no hypothesis about gender-specific effects of gender diversity. The younger people in our sample have spent more of their time with same-aged peers. If this familiarity breeds comfort, we have

Hypothesis 2b. Turnover among younger workers will increase with age diversity faster than will turnover among older workers.

\section{Isolation}

A subset of similarity theories predicts not just higher general turnover in more diverse workgroups, but higher turnover concentrated in the out-group: those who are in the numerical minority. Diversity is a characteristic of a workplace. Isolation is a characteristic that describes how unusual an individual is within a workgroup. If a group is $90 \%$ female and highly cohesive on average, the few men may not be included in the portion of the group that is cohesive and has repeated interactions (Pfeffer 1983; Greif 1993). ] The theory of workplace public goods also suggests that the minority group is (all else equal) less likely than the majority to find the mix of public goods satisfying. These theories predict that

Hypothesis 3a. Turnover is higher among employees with few coworkers of their gender.

Hypothesis 3b. Turnover is higher among employees with few coworkers of their race.
Hypothesis 3c. Turnover is higher among employees whose age substantially differs from the average age of their coworkers.

As with predictions from organizational diversity theory, predictions from theories of isolation have a mixed empirical record (contrast Riordan and Shore [1997] and Pelled [1996]).

\section{Do Isolation Effects Vary across Groups?}

These theories of worker preference for similar coworkers ignore groups' distinctive historical roles and status. Hence, a group that is $90 \%$ white is treated identically to one that that is $90 \%$ black. A complementary set of theories emphasizes social roles, stereotypes, status, hierarchy, and norms based on characteristics such as age, race, and gender (Akerlof and Kranton 2000; Eagly 1987). In these theories, whites and blacks (for example) both tend to treat blacks as holding lower status. Diversity now has a direction: different age, education, gender, and racial groups have normative, stereotypical, and historically typical roles and status determined in part outside the workplace.

These theories suggest that diversity has different effects on different groups, but the rankings of effects across status groups are not consistent across theories. Whites, for example, may be more used to working in homogeneous settings than are other groups. The average white has attended a high school that was $80 \%$ white, while Asian students on average have attended schools that were only $22 \%$ Asian, with black and Hispanic isolation in-between (calculated from Frankenberg, Lee, and Orfield 2003) . Isolation may, then, cause whites more discomfort than it would women and minorities (Tsui et al. 1992). If this dynamic is powerful, we have

Hypothesis 4a. Isolation increases turnover more for whites than for other racial groups.

In contrast, the effects of being a numerical minority or token may be mitigated for high-status groups because they do not face the expectations of failure and result- 
ing extra scrutiny that a low-status token might face (see, for example, Fairhurst and Snavely 1983; Kanter 1977). This suggests

Hypothesis 4b. Isolation increases turnover less for men, for whites, and for older employees than for the complementary groups.

These hypotheses compete in part because past research is mixed. Tsui et al. (1992) reported that the presence of minorities lowers whites' commitment and intent to stay. As the authors noted, this effect could be due to minorities being over-represented in undesirable jobs, and this omitted job characteristic, rather than minority coworkers, may lower whites' commitment. This interpretation is supported by their finding that the percent minority also reduces blacks' intention to stay with a substantively similar and statistically indistinguishable point estimate. In contrast, gender diversity has had similar effects on men and women.

Because gender is a binary variable, the interaction of gender isolation and female is collinear with the other measures needed to test relational theories (gender diversity, female x gender diversity, female employee, female manager, and gender isolation). Thus, we can only test these hypotheses for race and age.

\section{Other Dimensions of Diversity}

Do the effects of isolation vary depending on who is in the other groups?

Some races may react differently to specific other races. Race-specific interactions may occur, for example, if communication gaps are especially large between certain racial pairs or if discrimination or other sources of animosity are greater between certain racial pairs (Elvira, Zatrick, and Cohen 1998). For example, blacks historically have low status in American society. Hispanics also suffer from some discrimination and often come from a distinct culture. Language and accent barriers may further widen the social divide between Hispanics and non-Hispanics. Asians, in contrast, are sometimes stereotyped as the "model minority" (Wong et al. 1998). Thus, we have

Hypothesis 5a. Turnover of white employees is lower when coworkers are Asian than when they belong to other nonwhite groups.

There is some reason to expect disparagement of blacks to be less characteristic of the Hispanics in our sample than of the other non-black groups. This employer required employees to choose only one category when identifying their race/ ethnicity. Presumably some Hispanics in our sample would, if given the opportunity, also classify themselves as black or mixedrace, while some blacks in our sample would also consider themselves Hispanic. These forces yield

Hypothesis 5b. Turnover of black employees is lower when coworkers are Hispanic than when they are white.

Hypothesis 5c. Turnover of Hispanic employees is lower when coworkers are black than when they are white.

At the same time, some anecdotal reports have noted tension between blacks and Hispanics (for example, Goering et al. 2002:13), and Sacco and Schmidt (2005) did not find any difference in turnover rates for Hispanics depending on whether coworkers were white versus black.

\section{Tokens}

Tokens are the numerical extreme of isolation. To the extent that tokens face extra pressure and social isolation, isolation theories predict

Hypothesis 6a. Employees who differ from all their coworkers in sex or race, and employees who are either younger or older than all their coworkers, have above-average turnover.

Being a token need not affect all groups in the same way. The sole man in a work group is unlikely to experience the sexual and other forms of harassment that a lone woman frequently faces, and he may face less intense stereotyping (Kanter 1977; Fairhurst and Snavely 1983). Thus, we have

Hypothesis 6b. Turnover is not above-average for male tokens or white tokens. 
At the same time, if whites or men have had less experience as a minority, then being a token may be more stressful for these groups than for non-whites or women.

Hypothesis 6b'. Male and white tokens experience higher turnover than do other tokens.

\section{Similarity along multiple dimensions}

The many isolation theories outlined above do not describe which demographic boundaries or sets of boundaries are most salient in American workplaces. Perhaps due to limited sample sizes, past research has examined demographic dimensions as independent dimensions without attention to interactions of race and sex. But the effects of having many similar coworkers may be most intense when it is compounded along more than one demographic dimension. People may bond more strongly when coworkers share multiple characteristics. While the presence of some female coworkers may matter to the average woman, the presence of female coworkers of the same race may matter more. This theory predicts a testable interaction effect (coworkers of the same race and same sex):

Hypothesis 7. Turnover is less likely for employees whose coworkers share multiple characteristics with them than for those whose coworkers share only one characteristic with them, and this effect is larger than would be predicted by the main effects on the characteristics individually.

\section{Isolation from customers}

Just as demographic distance among coworkers can affect the ease and comfort of their relationship, the distance between workers and potential customers can affect their relationship. A related literature explores the hypothesis that customers prefer to deal with demographically similar employees. One important study finds that newly hired low-wage workers who have direct contact with customers are more likely to match the demographics of those customers than are new hires who have no customer contact (Holzer and Ihlanfeldt 1988). Similarly, restaurants hire work forces with demographic characteristics that approximate those of their clients (Neumark 1996). These employers act as if customers discriminate. (For suburbanurban differences, see Holzer, Raphael, and Stoll 2000.) Whether customers do actually discriminate is a distinct question (see the citations in Leonard and Levine 2002). Although the evidence is mixed, and the practice can lead to employment discrimination litigation, many managers and management consultants advocate hiring a work force that matches the demographics of potential customers in the belief that customers prefer to deal with demographically similar employees.

An important twist on this argument is that if customers are more comfortable with and have an easier time communicating with demographically similar employees, then the same effect may operate in reverse. That is, employees may experience lower psychic costs in serving demographically similar customers than in serving demographically dissimilar ones. These forces lead to

Hypothesis 8. Turnover is higher among employees who are demographically dissimilar to potential customers than among those who are demographically similar.

\section{Data and Methods}

The usual downside of field research is the availability of only a limited number of observations, which limits the power of statistical tests. We examine over 800 workplaces and over 70,000 employees. Our total number of workgroups is roughly the total number of natural workgroups in all the field studies reviewed by Williams and O'Reilly (1998).

Our focus on one very large multi-establishment employer-a company that actively seeks uniformity of process and product across establishments-controls for most of the variation in job characteristics that confound other field studies of diversity. Examining almost-identical jobs is important because in most sectors of the economy the presence of women, blacks, or Hispanics in a workplace or occupation is strongly 
correlated with the characteristics of the workplace and occupation.

Workplace demographics are also correlated with the local economy; for example, blacks are disproportionately concentrated in poorer neighborhoods than are whites. We examine longitudinal data permitting a set of workplace-specific intercepts to control for the locational differences that have plagued all previous field studies of workgroup diversity.

The data used in this study are unique among studies of organizational demography in having a sufficiently large sample size and workgroups sufficiently disparate in composition to allow examination of both diversity and the main effect of percent female, percent black, and percent Hispanic. The data are rich and varied enough to allow us to distinguish a number of theoretically and empirically distinct measures of workplace demographics. We distinguish (1) the main (linear) effect of workgroup demographics; (2) diversity, identified as a non-linear effect of workplace demographic shares; (3) isolation, or being in a numerical minority of the workplace; and (4) the extreme of isolation, the effect of being a token individual at the workplace (for example, the only black or male).

We also examine how diversity and isolation affect different demographic groups (men versus women, whites versus other races, and so on) differently. The literature on racial diversity focuses almost exclusively on blacks and whites (Reskin et al. 1999:357), in spite of the fact that the racial and ethnic palette in this country is a broad and varied one. The numbers of whites, blacks, Hispanics, and Asians in our sample are large enough to allow us to examine each group. While the study has many strengths, it remains a case study of one large employer in the retail and services sector in a time of relative labor-market tightness.

The data are the complete personnel records from a large service-sector employer from February 1996 to October 1998. We analyze data on frontline workplace employees, excluding managers, assistant managers, and headquarters or international staff. Because we want workplace averages to be reliable measures, we drop workplaces with fewer than ten employees. Because we are interested in voluntary exits, we also drop workplaces that closed within our sample period.

We examine the employment spells of more than 70,000 workers first hired by this company between February 1996 and December 1997. Each observation begins with the hiring or rehiring of an employee and ends either at the point when the employee exits (if the exit occurs within six months) or at the end of six months (if no exit occurs during that period). Approximately $13 \%$ of the work force analyzed here had multiple employment spells. Our data cover more than 800 workplaces with at least 10 employees that were open during this period and stayed open until at least July 1998.

To map community demographics, we first identified Census tracts in each workplace's ZIP code or within two miles of the centroid of its ZIP code, then merged 1990 Census data for this local region to each workplace to construct the proportion white, black, Hispanic, and Asian surrounding each workplace. The 1990 Census asks questions on race (black versus white, for example) separately from ethnicity (Hispanic versus non-Hispanic). In the Census, respondents can categorize themselves as both black and Hispanic or as both white and Hispanic. In contrast, the employer has mutually exclusive codes for white, black, and Hispanic (as well as Asian).

\section{The Setting}

The workplaces we studied typically consisted of 10 to 40 part-time employees with a full-time manager or assistant manager on duty. The employees worked scattered shifts through the week, associating with a mix of the other employees on the payroll during each shift. Frontline employees rotated through the several tasks in the workplace, spending some of their time dealing with customers and other time in support tasks.

Employees received minimal training or 
orientation. Some self-selection may have occurred because of the popular image of this employer. Advertisements show a demographically diverse (though consistently young) group of customers. Managers (unlike new hires) did receive some training in managing a diverse work force.

According to exit interviews, roughly $82 \%$ of exits from employment were quits, $10 \%$ were layoffs (typically due to end of seasonal work), and $8 \%$ were dismissals for cause. There is an unknown amount of misclassification in these categories (for example, induced quits, dismissal due to absences that are truly a quit, and so forth). For our principal analysis, we treat all exits (our dependent variable) as voluntary separations, but we also briefly describe the results of alternate analyses that yield similar results using other measures of exits. The exits of the relatively isolated are more likely to reflect employee preferences than employer or manager preferences. After all, the workplace manager hired the people we observe. Differences in quit propensities or employer discrimination associated with race, ethnicity, age, or sex would show up in the individual or group main effects, rather than in the diversity measures.

The high employee turnover in this sector makes it useful for studying the effects of changing demographics. Roughly half of new hires left within four months of being hired (a rate typical of retail). Testing diversity theories with the sample of workers flowing into the organization avoids a problem that would arise if we started with the entire stock of employees: retention is determined in part by the demographic mix of the workplace, but the demographic mix of still-present colleagues depends in part on the focal employees' demographics. We study hires who have as yet had little chance to affect their colleagues' turnover.

The nature of the workplaces and work populations involved in this study should be kept in mind in thinking about possible effects. Consider the example of age diversity. The employees of this firm and this industry tend to be young. The relatively low pay and lack of promotional opportuni- ties means we are not seeing older workers who have moved up the job ladder or very many workers with good job alternatives.

\section{Methods}

We analyze turnover within the first six months of hire. We first use a nonparametric graphical analysis to look at differences in turnover rates for the various demographic groups at workplaces with different demographic mixes. This method is basically a smoothed histogram of turnover rates separately for men and for women at workplaces with differing proportions of female employees. Histograms are affected by bumps due to random factors. To avoid these misleading points, we use a locally weighted technique that smooths the predicted values of turnover. ${ }^{5}$

To focus on changes over time at a workplace, we then estimate a linear probability model with a fixed effect for each workplace. A Hausman test strongly rejects the random effects model in favor of the fixed effects model we present here. Any workplace- or location-specific omitted variable, such as local labor market conditions, that is unchanging over the few years we observe is captured in the fixed effect.

The sign, significance, and relative magnitude of all coefficients were unchanged in a fixed effects (conditional) logit regression that included a separate intercept for each workplace, and in a continuous time hazard model with workplace fixed effects (the Cox proportional hazard model). As it is more straightforward to interpret the magnitude of the coefficients with the linear probability model, we rely on that specification.

Because demographics change during an employee's tenure, our results may suffer modest attenuation because we measure demographics only at the date of hire.

\footnotetext{
${ }^{5}$ Formally, we use the Stata lowess estimator with a tricube weighting scheme and a bandwidth of .15. Results were not sensitive to variations in the bandwidth. See Stata (2000:173) for the specific methods and formulae.
} 
Below we discuss results that adjust for both demographics at hire date and the (partly endogenous) changes in demographics over time.

\section{Measuring Diversity}

We construct diversity indices for the race, gender, and age of the other employees in the workplace. For race and gender, we use a diversity index equal to the odds that two people selected at random from a workplace differ on race or gender (first used by E. H. Simpson 1949). The diversity index is one minus the sum of the demographic shares squared (also known as 1 minus the Herfindahl Index):

Diversity index on race or gender $=$

$$
1-\Sigma_{i} S_{i}^{2}
$$

where $S_{i}$ is the share of each gender or racial group $i$. This diversity index is zero with perfect homogeneity and is maximized when each group has an equal share of employment. $^{6}$

Most past researchers have used the coefficient of variation on age or the standard deviation of age to measure age diversity. We prefer to use the standard deviation within the workgroup of the natural logarithm of age. This formulation assumes that proportional gaps in age are what lead to social distance.

As noted above, traditionally high-status groups such as men, whites, or older workers may differ from lower-status groups such as women, blacks and Hispanics, and younger workers in the way they react when they find themselves in the minority. To capture this, we interact the workgroup diversity measures with dummy variables for gender, race, and age.

Finally, we examine the effect of tokenism: being the only man or woman, the only one of a given race, or the oldest or

\footnotetext{
${ }^{6} \mathrm{~A}$ maximally diverse workplace is not necessarily identical to one selected in a race- or gender-blind fashion, because demographic shares of the relevant labor pools need not be equal.
}

youngest employee in the workplace in a given month.

\section{Distinguishing Diversity from Main Demographic Group Effects}

It is often incorrectly assumed that diversity must increase with increasing minority or female share. This is easily shown to be wrong. Gender diversity reaches its maximum in a workplace that is half female. As the percentage female increases further toward $100 \%$, diversity falls toward zero. While both the 50:50 and the female-only workplaces both differ from the stereotypically male-dominated workplace, only the former is gender-diverse.

To identify the effect of gender diversity requires observations of some settings in which women comprise more than half of employees and other settings in which they comprise less than half of the employees. In most empirical work few if any workgroups have a female or nonwhite majority. In that situation, percent female or percent white and a measure of gender or racial diversity are collinear, and researchers cannot empirically disentangle the main effect from the effect of diversity. This study has sufficiently rich data to distinguish the effects of the proportion of women and nonwhites from the effects of gender and racial diversity.

We define diversity as a nonlinear effect. To be clear, as the proportion female in a workplace increases from zero to half, both the main effect of percent female and the effect of diversity grow. As the proportion female increases from half to one, the effect of percent female continues to increase, but that of diversity falls. This is the nonlinearity we use to identify the effect of diversity distinct from the main demographic effects.

\section{Isolation}

Isolation measures being in a numerical minority in a workgroup: the percentage unlike the focal worker. Consider two examples: for women, gender isolation is the percentage male; for Asians, racial/ethnic 
isolation is the percentage non-Asian. For age we use the difference from workgroup mean log age, which is approximately the percentage difference between the individual's age and the mean age of the rest of the workgroup. ${ }^{7}$ To look at the interaction of age isolation and age, we interact the absolute deviation of own $\log$ age minus the log of workgroup mean age with own age.

For race isolation, the measure AsIan $x$ \%AsIAN can be rewritten as AsIAN $\times(1-$ $\%$ White $-\%$ BLACK $-\%$ HisPanic $)=\%$ Asian Asian x \% White - Asian x \% Black - Asian $x$ $\%$ Hispanic. Including the (Asian $x$ \% Asian) term alone implicitly assumes that the three race interactions AsIAN $\times \%$ White, Asian $\times$ $\%$ Black, Asian $\times \%$ Hispanic have identical effects on Asian exits; in other words, that Asians care about working with other Asians, but are indifferent to the race of the nonAsians. To test Hypotheses $5 \mathrm{a}-\mathrm{c}$, that some groups are not indifferent to the mixture of races of coworkers not of their race, we

${ }^{7}$ Researchers in organizational behavior usually analyze a different indicator of isolation $\left(d_{i}\right.$, known as "relational demography"), which equals the average Euclidean distance between how far each person in group $g$ is from each other person on trait $t$ :

$$
d_{i t}=1 / n_{g}\left[\sum_{j}\left(x_{i t}-x_{j t}\right)^{2}\right]^{1 / 2}, j=1 \text { to } n_{g},
$$

where $x i t$ is the focal person's measure of attribute $t$, $x j t$ is the measure for others in the group, $t$ indexes the attributes (race, sex, and nationality, for example), and $n g$ is the number of members in the group (Tsui and O'Reilly 1989). The relational demography measure ditcan be rewritten as a nonlinear average of (1) the gap between person $i$ on the trait and the mean of that trait in the group $\left(x_{g t}\right)$, and (2) the standard deviation of the trait within the group $(\operatorname{sd}(x i t))$ :

$$
d_{i t}=\left[\left|x_{i t}-x_{g t}\right|^{2}+\operatorname{sd}\left(x_{i t}\right)^{2}\right]^{1 / 2} .
$$

Conceptually, person $i$ can differ by roughly 5 years of age for the relational demography measure dit by (a) being 25 years old in a group where everyone else is 20 ; or (b) being the mean age of a group that has a standard deviation of age of 5 years. Being the mean age of a heterogeneous group may indicate weak norms (as discussed above), while being the outlier in an otherwise homogeneous group raises the likelihood that strong norms exist but are unfavorable to oneself. We prefer to enter the two effects of isolation $\left(\left|x_{i t}-x_{g t}\right|\right)$ and of diversity $\left(\operatorname{sd}\left(x_{i t}\right)\right)$ separately, without assuming a particular functional form. include the three race interactions Asian $x$ $\%$ White, Asian $\times$ \% Black, and Asian $\times \%$ HisPANIC for Asians and the analogous three interactions for the other three groups and test whether the interactions differ.

\section{Control Variables}

We control for whether the individual is hired as a part-time employee (over a third of the sample) or temporary employee (over half the sample). Consistent with the lowwage, high-turnover status of these jobs, over $90 \%$ of the sample were hired as part-time or temporary employees. Many temporary workers later switched to permanent status, a choice not studied here. To capture seasonal and secular effects, we also include 20 dummies for month of hire.

Control variables include an indicator variable for each employee's gender and for six race or ethnicity categories (white, black, Asian, Hispanic, Native American, and unknown ethnicity). The race and ethnicity codes are those used by the company, and they create a set of mutually exclusive and collectively exhaustive categories that (for simplicity) we refer to as "race." We control for the worker's age and its square.

We also control for the percentage of each gender and race and for the mean age for all workers in the workplace surrounding (but not including) the focal employee. When the numerical majority determines norms of an organization, then the typical behavior of any group (as measured in the individual effects) spills over when it becomes the majority. This yields the hypothesis that the effects of the proportion female, black, and so on at the workplace level will have the same sign as the individual-level coefficients. The same spillover result could also occur because employees who have little or no intention to remain invest less in building relationships in the workplace; thus, their colleagues are also more likely to quit (as modeled by Glaeser et al. 2000). Offsetting this effect, if promotions and other rewards are at least partly based on relative competition, then 
there may be one group of employees who do well and are less likely to quit, while their unsuccessful colleagues are more likely to leave.

\section{Results}

Summary statistics are presented in Table 1. Although the sample was twothirds white, almost a quarter of the workplaces had a nonwhite majority. Such workplaces were typically quite diverse, with fewer than $10 \%$ having a majority of employees who were a single nonwhite group. The work force was $71 \%$ female, and about $5 \%$ of the workplaces had a male majority. The mean age of employees in our data was only 22 years. The standard deviation of $\log$ (age) is $6 \%$, a very small figure. Most employees in these workplaces were within a few years of age 22. Thus, any employees in their thirties or older may have had low labormarket attachment or may have been reentering the labor market; either could reverse the usual negative effect of age on turnover.

We observe workplaces over practically the entire range of gender and race diversity. With two sexes, the maximum of the gender diversity index is .5 , and with our five ethnic/racial groups, the maximum racial diversity index is .8 . In our study, the observed maximums are .5 and .795 , respectively. Mean gender diversity was .36, and mean racial diversity was .39 . In the absence of comparable diversity measures for other U.S. establishments, we can only say that we believe these establishments were unusually diverse in terms of gender and race, and unusually homogeneous in terms of age.

\section{Regression Results}

Table 2 presents the main results of the paper, estimates of the probability of turnover six months after hire or rehire with fixed effects (not shown) for each workplace and for each month. To adjust for common shocks to a workplace, in addition to including the workplace fixed effects we adjust standard errors for clustering by the workplace $\mathrm{x}$ month. ${ }^{8}$

Column (1) presents the baseline results with standard controls for individual and workplace characteristics, and for the mean race, sex, and age composition within each workplace. Compared with whites (the omitted racial category), blacks had slightly higher turnover, while Hispanics and Asians had slightly lower turnover. As expected, both part-time and temporary seasonal workers were more likely to leave than were full-time and permanent workers. Women, in contrast, were more likely to stay than were men. All these coefficients are strongly statistically significant. ${ }^{9}$ Consistent with most other studies, turnover falls with age. These results are not due to differences in starting wages or in workplace size, which are directly controlled for. ${ }^{10}$ The usual results that turnover falls with wages and rises with establishment size prevail here as well.

The heartening news here is that, in the linear specification, employees' quit behavior is not very responsive to the demographic composition of a workplace. The workplace demographic variables-gender proportions, race proportions, and mean age-have no statistically significant associations with turnover.

\section{Diversity}

The results of our estimation of the effects of diversity on particular groups are

\footnotetext{
${ }^{8}$ This correction solves the problem of correlated error terms that is also addressed by hierarchical models (Stata 2005:275-80). Our clustering correction permits arbitrary between-cluster correlations; thus, it corrects for auto-correlated errors in a store's time series due to having largely the same workers in adjacent months at a workplace.

${ }^{9}$ In contrast, in most studies black and white turnover rates are similar, and women quit more than men. As others have found (for example, Blau and Kahn 1981), controlling for job characteristics typically reduces or eliminates the gender gap in quitting.

${ }^{10}$ Across demographic groups hired in a given workplace during the same month, there were no economically meaningful differences in starting wages.
} 
Table 1. Summary Statistics.

\begin{tabular}{|c|c|c|c|c|}
\hline Variable & Mean & Std. Dev. & Min & $\operatorname{Max}$ \\
\hline Turnover within 6 Months of Hire & .64 & & & \\
\hline \multicolumn{5}{|l|}{ Baseline Demographics } \\
\hline $\begin{array}{l}\text { FEMALE } \\
\text { WHITE } \\
\text { BLACK } \\
\text { HISPANIC } \\
\text { ASIAN/PACIFIC ISLANDER } \\
\text { NATIVE AMERICAN } \\
\text { UNKNOWN ETHNICITY } \\
\text { AGE AT TIME OF HIRE } \\
\text { PART-TIME EMPLOYEE } \\
\text { TEMPORARY/SEASONAL EMPLOYEE }\end{array}$ & $\begin{array}{c}0.708 \\
0.655 \\
0.160 \\
0.100 \\
0.068 \\
0.004 \\
0.013 \\
22.33 \\
0.346 \\
0.611\end{array}$ & 6.69 & 15 & 80 \\
\hline \multicolumn{5}{|l|}{ Workplace Means } \\
\hline $\begin{array}{l}\text { WORKPLACE \%FEMALE } \\
\text { WORKPLACE \%WHITE } \\
\text { WORKPLACE \%BLACK } \\
\text { WORKPLACE \%HISPANIC } \\
\text { WORKPLACE \%ASIAN } \\
\text { \%NATIVE AMERICAN \& UNKNOWN } \\
\text { WORKPLACE MEAN AGE }\end{array}$ & $\begin{array}{r}0.735 \\
0.696 \\
0.128 \\
0.097 \\
0.063 \\
0.017 \\
24.14\end{array}$ & $\begin{array}{l}0.126 \\
0.227 \\
0.135 \\
0.135 \\
0.080 \\
0.030 \\
2.14\end{array}$ & $\begin{array}{l}0.139 \\
0.000 \\
0.000 \\
0.000 \\
0.000 \\
0.000 \\
18.46\end{array}$ & $\begin{array}{l}1.000 \\
1.000 \\
0.929 \\
1.000 \\
0.704 \\
0.585 \\
41.44\end{array}$ \\
\hline \multicolumn{5}{|l|}{ Workplace Diversity } \\
\hline $\begin{array}{l}\text { GENDER DIVERSITY INDEX }= \\
1-\left[(\% \text { FEMALE })^{2}+(\% \text { MALE })^{2}\right] \\
\text { RACIAL DIVERSITY INDEX }=1-\left[(\% \text { WHITE })^{2}+\right. \\
\left.(\% \text { BLACK })^{2}+(\% \text { HISPANIC })^{2}+(\% \text { ASIAN })^{2}\right] \\
\text { WORKPLACE Sd }(\text { LOG AGE })\end{array}$ & $\begin{array}{l}0.358 \\
0.390 \\
0.268\end{array}$ & $\begin{array}{l}0.123 \\
0.206 \\
0.060\end{array}$ & $\begin{array}{l}0.000 \\
0.000 \\
0.078\end{array}$ & $\begin{array}{l}0.500 \\
0.795 \\
0.585\end{array}$ \\
\hline \multicolumn{5}{|l|}{ Isolation } \\
\hline $\begin{array}{l}\text { WORKPLACE } \% \text { (NOT MY SEX) } \\
\text { WORKPLACE } \% \text { (NOT MY RACE) } \\
\mid \log (\text { AGE })-\log (\text { WORKPLACE MEAN AGE)| }\end{array}$ & $\begin{array}{l}0.383 \\
0.414 \\
0.219\end{array}$ & $\begin{array}{l}0.240 \\
0.317 \\
0.153\end{array}$ & $\begin{array}{l}0.000 \\
0.000 \\
0.000\end{array}$ & $\begin{array}{l}1.000 \\
1.000 \\
1.324\end{array}$ \\
\hline $\begin{array}{l}\text { Tokens } \\
\text { TOKEN MAN IN WORKPLACE } \\
\text { TOKEN WHITE IN WORKPLACE } \\
\text { TOKEN BLACK IN WORKPLACE } \\
\text { TOKEN HISPANIC IN WORKPLACE } \\
\text { TOKEN ASIAN IN WORKPLACE } \\
\text { TOKEN NATIVE AMERICAN IN WORKPLACE } \\
\text { YOUNGEST IN WORKPLACE } \\
\text { OLDEST IN WORKPLACE }\end{array}$ & $\begin{array}{l}0.003 \\
0.00005 \\
0.008 \\
0.007 \\
0.009 \\
0.003 \\
0.068 \\
0.003\end{array}$ & & & \\
\hline \multicolumn{5}{|l|}{ Interactions } \\
\hline $\begin{array}{l}\text { FEMALE } \times(\text { GENDER DIVERSITY INDEX }) \\
\text { WHITE } \times(\text { RACIAL DIVERSITY INDEX }) \\
\text { BLACK } \times(\text { RACIAL DIVERSITY INDEX }) \\
\text { HISPANIC } \times(\text { RACIAL DIVERSITY INDEX }) \\
\text { ASIAN } \times(\text { RACIAL DIVERSITY INDEX }) \\
\log (\text { AGE }) \times \operatorname{sd}(\log (\text { AGE })) \\
\log (\text { AGE }) \times \mid \log (\text { AGE })- \\
\log (\text { WORKPLACE MEAN AGE } \mid\end{array}$ & $\begin{array}{l}0.244 \\
0.219 \\
0.079 \\
0.051 \\
0.033 \\
0.824\end{array}$ & $\begin{array}{l}0.190 \\
0.223 \\
0.195 \\
0.166 \\
0.132 \\
0.197 \\
0.529\end{array}$ & $\begin{array}{l}0.000 \\
0.000 \\
0.000 \\
0.000 \\
0.000 \\
0.235\end{array}$ & $\begin{array}{l}0.500 \\
0.795 \\
0.789 \\
0.789 \\
0.783 \\
2.211\end{array}$ \\
\hline
\end{tabular}

Notes: Percentages for a workplace do not include the focal individual. N > 70,000 hires at over 800 workplaces. Variables with "\%," "MEAN," "SD," or "INDEX" in their name are computed at the workplace level. Dummy variables do not report SD, min., or max. 
shown in column (2). In results not shown, the main effects of gender diversity, race diversity, and age diversity are small and not statistically significant (providing no support for Hypothesis 1). That result masks the varying effects of diversity on some groups.

Men's turnover rate was unaffected by gender diversity. Women, in contrast, left diverse workplaces more often than workplaces with high shares of men or high shares of women; the coefficient of Female $\times($ Gender Diversity Index $)$ is $.17(\mathrm{p}<.01)$. This is almost the only result consistent with the hypothesis that diversity promotes turnover.

Diversity had no effect on whites. The main effect of Racial Diversity Index in column (2) is small and not statistically significant. For the other groups, turnover was lower in more diverse work forces, and diversity reduced turnover most heavily for Hispanics (coefficient on HISPANIC $\times$ RaciaL DiVERSITY INDEX $=-.25, \mathrm{p}<.01)$. If one could hold everything constant while increasing the diversity index by .25 (about two standard deviations), this model predicts Hispanic turnover would decrease by 6 percentage points (about a tenth of the mean). Overall, these results provide no support for Hypothesis 2a that diversity increases turnover for whites the most and Asians the least; instead, diversity has no effect on whites and reduces turnover for Hispanics the most.

When diversity changes, the demographics of the workplace must also change. In most cases raising diversity implies increasing the share of Asians, Hispanics, or blacks. In column (2), the main effects of the proportion Asian and Hispanic both predict higher turnover, while the black effect is negligible. The linear main effects (which increase turnover) work in the opposite direction of the non-linear diversity effect (which for most groups reduces turnover).

There is no strong evidence that age diversity mattered more for the young than for the older ones (Hypothesis 2b). The coefficient on $\log \left(\mathrm{AGE}_{\mathrm{G}}\right) \times \operatorname{sd}(\log (\mathrm{AGE}))$ in column (4) is not statistically significant.
Figure 1. Gender and Predicted Turnover. (Results from Table 2, column 3)

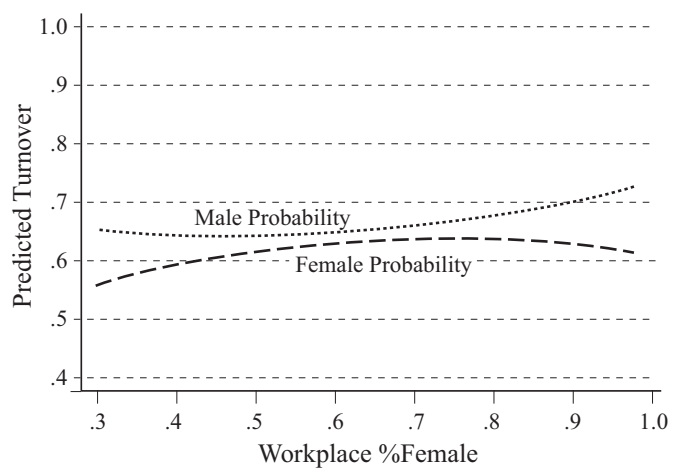

Note: The lower average level of the female turnover rate and the difference in curvature between the graphs for men and women are both statistically significant at the $1 \%$ level.

\section{Isolation}

Column (3) of Table 2 adds the measures of isolation (being in a numerical minority). Being relatively isolated by gender had no consistent impact on retention, contrary to Hypothesis 3a. For women, the isolation and diversity effects largely offset each other when women were in the majority. The total of the several effects is best viewed in Figure 1. When men were in the majority, female turnover rates declined. In contrast, male turnover rates were highest when women were a large majority.

Perhaps the most robust result in this study is the finding that racial isolation predicts higher turnover, consistent with Hypothesis $3 \mathrm{~b}$. Even here, the effect size is modest: a $32 \%$ reduction in the number of colleagues of the same race (one standard deviation across workplaces) raised turnover at 6 months by about 2.6 percentage points.

Once again, to correctly interpret these coefficients, bear in mind that as isolation changes, other racial shares must change as well. The full effect of isolation is the sum of the isolation effect, the diversity effect, and the shifts in the main effect on those races that rise or fall to increase diversity. To take one numerical example, if the white 
Table 2. Linear Fixed Effects Regressions Predicting Turnover within 6 Months.

\begin{tabular}{|c|c|c|c|c|}
\hline Variable & $\begin{array}{c}\text { (1) } \\
\text { Baseline }\end{array}$ & $\begin{array}{c}\text { (2) } \\
\text { Diversity }\end{array}$ & $\begin{array}{c}\text { (3) } \\
\text { Isolation }\end{array}$ & $\begin{array}{c}\text { (4) } \\
\text { Age Interactions } \\
+ \text { Tokens }\end{array}$ \\
\hline AGE AT TIME OF HIRE & $\begin{array}{l}-0.002 * * * \\
(0.000)\end{array}$ & $\begin{array}{l}-0.001 * * * \\
(0.000)\end{array}$ & $\begin{array}{l}-0.004 * * * \\
(0.000)\end{array}$ & $\begin{array}{l}-0.018 * * * \\
(0.002)\end{array}$ \\
\hline $\begin{array}{l}\text { AGE SQUARED (centered at mean, } \\
\text { coefficient multiplied by 100) }\end{array}$ & $\begin{array}{l}-0.001 * * * \\
(0.000)\end{array}$ & $\begin{array}{l}-0.001 * * * \\
(0.000)\end{array}$ & $\begin{array}{l}0.001 * * * \\
(0.000)\end{array}$ & $\begin{array}{l}-0.003 * * * \\
(0.000)\end{array}$ \\
\hline FEMALE & $\begin{array}{l}-0.032 * * * \\
(0.003)\end{array}$ & $\begin{array}{l}-0.098 * * * \\
(0.011)\end{array}$ & $\begin{array}{l}-0.180 * * * \\
(0.043)\end{array}$ & $\begin{array}{l}-0.193 * * * \\
(0.046)\end{array}$ \\
\hline BLACK & $\begin{array}{l}0.041^{* * * *} \\
(0.004)\end{array}$ & $\begin{array}{l}0.104 * * * \\
(0.011)\end{array}$ & $\begin{array}{c}0.010 \\
(0.020)\end{array}$ & $\begin{array}{c}0.008 \\
(0.021)\end{array}$ \\
\hline ASIAN & $\begin{array}{l}-0.017 * * * \\
(0.006)\end{array}$ & $\begin{array}{l}0.038 * * * \\
(0.014)\end{array}$ & $\begin{array}{l}-0.055^{* *} \\
(0.022)\end{array}$ & $\begin{array}{l}-0.057 * * \\
(0.024)\end{array}$ \\
\hline HISPANIC & $\begin{array}{l}-0.029 * * * \\
(0.005)\end{array}$ & $\begin{array}{l}0.089 * * * \\
(0.014)\end{array}$ & $\begin{array}{l}-0.007 \\
(0.022)\end{array}$ & $\begin{array}{l}-0.010 \\
(0.023)\end{array}$ \\
\hline NATIVE AMERICAN & $\begin{array}{c}0.032 \\
(0.021)\end{array}$ & $\begin{array}{l}0.062 * * \\
(0.031)\end{array}$ & $\begin{array}{c}0.000 \\
(0.000)\end{array}$ & $\begin{array}{l}0.000 \\
(0.000)\end{array}$ \\
\hline UNKNOWN ETHNICITY & $\begin{array}{c}0.009 \\
(0.012)\end{array}$ & $\begin{array}{c}0.039 \\
(0.027)\end{array}$ & $\begin{array}{c}0.000 \\
(0.000)\end{array}$ & $\begin{array}{l}0.000 \\
(0.000)\end{array}$ \\
\hline PART-TIME & $\begin{array}{c}0.019 \\
(0.010)\end{array}$ & $\begin{array}{c}0.018 \\
(0.010)\end{array}$ & $\begin{array}{c}0.016 \\
(0.010)\end{array}$ & $\begin{array}{l}0.010 \\
(0.010)\end{array}$ \\
\hline TEMPORARY/SEASONAL & $\begin{array}{l}0.092 * * * \\
(0.010)\end{array}$ & $\begin{array}{l}0.091 * * * \\
(0.010)\end{array}$ & $\begin{array}{l}0.090 * * * \\
(0.010)\end{array}$ & $\begin{array}{l}0.086^{* * *} \\
(0.010)\end{array}$ \\
\hline STARTING HOURLY WAGE & $\begin{array}{l}-0.010 * * * \\
(0.002)\end{array}$ & $\begin{array}{l}-0.011 * * * \\
(0.002)\end{array}$ & $\begin{array}{l}-0.012 * * * \\
(0.002)\end{array}$ & $\begin{array}{l}-0.011 * * * \\
(0.002)\end{array}$ \\
\hline WORKPLACE TOTAL EMPLOYMENT & $\begin{array}{l}0.001 * * * \\
(0.000)\end{array}$ & $\begin{array}{l}0.001 * * * \\
(0.000)\end{array}$ & $\begin{array}{l}0.001 * * * \\
(0.000)\end{array}$ & $\begin{array}{l}0.001 * * * \\
(0.000)\end{array}$ \\
\hline WORKPLACE \% FEMALE & $\begin{array}{c}0.048 \\
(0.029)\end{array}$ & $\begin{array}{c}0.115 \\
(0.063)\end{array}$ & $\begin{array}{c}0.097 \\
(0.064)\end{array}$ & $\begin{array}{c}0.085 \\
(0.064)\end{array}$ \\
\hline WORKPLACE \%BLACK & $\begin{array}{l}-0.033 \\
(0.036)\end{array}$ & $\begin{array}{l}-0.016 \\
(0.054)\end{array}$ & $\begin{array}{l}-0.003 \\
(0.054)\end{array}$ & $\begin{array}{c}0.002 \\
(0.054)\end{array}$ \\
\hline WORKPLACE \%ASIAN & $\begin{array}{c}0.079 \\
(0.052)\end{array}$ & $\begin{array}{c}0.106 \\
(0.074)\end{array}$ & $\begin{array}{c}0.111 \\
(0.073)\end{array}$ & $\begin{array}{l}0.110 \\
(0.073)\end{array}$ \\
\hline WORKPLACE \%HISPANIC & $\begin{array}{c}0.052 \\
(0.048)\end{array}$ & $\begin{array}{c}0.073 \\
(0.063)\end{array}$ & $\begin{array}{c}0.074 \\
(0.063)\end{array}$ & $\begin{array}{c}0.079 \\
(0.063)\end{array}$ \\
\hline $\begin{array}{l}\text { WORKPLACE \% OTHER } \\
\text { (Native American + Unknown) }\end{array}$ & $\begin{array}{c}0.007 \\
(0.086)\end{array}$ & $\begin{array}{c}0.045 \\
(0.101)\end{array}$ & $\begin{array}{l}-0.074 \\
(0.097)\end{array}$ & $\begin{array}{l}-0.076 \\
(0.096)\end{array}$ \\
\hline WORKPLACE MEAN AGE & $\begin{array}{c}0.001 \\
(0.002)\end{array}$ & $\begin{array}{c}0.001 \\
(0.002)\end{array}$ & $\begin{array}{l}0.009 * * * \\
(0.002)\end{array}$ & $\begin{array}{l}0.017 * * * \\
(0.002)\end{array}$ \\
\hline $\begin{array}{l}\text { GENDER DIVERSITY INDEX = } \\
1-\left[(\% \text { FEMALE })^{2}+(\% \text { MALE })^{2}\right]\end{array}$ & & $\begin{array}{c}\mathbf{- 0 . 0 4 2} \\
(0.068)\end{array}$ & $\begin{array}{c}\mathbf{- 0 . 1 4 3} \\
(0.084)\end{array}$ & $\begin{array}{c}-\mathbf{0 . 1 6 7} \\
(0.088)\end{array}$ \\
\hline $\begin{array}{l}\text { RACIAL DIVERSITY INDEX }= \\
1-\left[(\% \text { WHITE })^{2}+(\% \text { BLACK })^{2}+\right. \\
\left.(\% \text { HISPANIC })^{2}+(\% \text { Asian })^{2}+(\% \text { Other })^{2}\right]\end{array}$ & 0.028 & $\begin{array}{c}-\mathbf{0 . 0 4 4} \\
(0.045)\end{array}$ & $\begin{array}{c}-\mathbf{0 . 0 4 9} \\
(0.046)\end{array}$ & $(0.046)$ \\
\hline WORKPLACE sd(Log Age) & & $\begin{array}{c}\mathbf{0 . 0 0 7} \\
(0.071)\end{array}$ & $\begin{array}{c}\mathbf{- 0 . 0 2 4} \\
(0.072)\end{array}$ & $\begin{array}{c}\mathbf{0 . 6 1 0} \\
(0.361)\end{array}$ \\
\hline FEMALE $\times($ GENDER DIVERSITY INDEX $)$ & & $\begin{array}{l}\mathbf{0 . 1 7 2} * * * \\
(0.028)\end{array}$ & $\begin{array}{l}\mathbf{0 . 3 2 1} * * * \\
(0.077)\end{array}$ & $\begin{array}{l}\mathbf{0 . 3 4 2} * * * \\
(0.082)\end{array}$ \\
\hline BLACK $\times($ RACIAL DIVERSITY INDEX $)$ & & $\begin{array}{l}-\mathbf{0 . 1 4 9 * * *} \\
(0.022)\end{array}$ & $\begin{array}{c}-\mathbf{0 . 0 2 7} \\
(0.031)\end{array}$ & $\begin{array}{c}-\mathbf{0 . 0 1 9} \\
(0.032)\end{array}$ \\
\hline ASIAN $\times($ RACIAL DIVERSITY INDEX) & & $\begin{array}{l}-\mathbf{0 . 1 3 2} * * * \\
(0.029)\end{array}$ & $\begin{array}{l}\mathbf{- 0 . 0 3 0} \\
(0.035)\end{array}$ & $\begin{array}{c}-\mathbf{0 . 0 3 1} \\
(0.037)\end{array}$ \\
\hline
\end{tabular}


Table 2. Continued.

\begin{tabular}{|c|c|c|c|c|}
\hline Variable & $\begin{array}{c}\text { (1) } \\
\text { Baseline }\end{array}$ & $\begin{array}{c}\text { (2) } \\
\text { Diversity }\end{array}$ & $\begin{array}{c}\text { (3) } \\
\text { Isolation }\end{array}$ & $\begin{array}{c}(4) \\
\text { Age Interactions } \\
+ \text { Tokens }\end{array}$ \\
\hline HISPANIC $¥$ (RACIAL DIVERSITY INDEX) & & $\begin{array}{l}-\mathbf{0 . 2 4 6 * * *} \\
(0.027)\end{array}$ & $\begin{array}{l}-\mathbf{0 . 1 2 3} * * * \\
(0.035)\end{array}$ & $\begin{array}{l}-\mathbf{0 . 1 2 1} * * * \\
(0.036)\end{array}$ \\
\hline GENDER ISOLATION $=\%($ NOT MY SEX $)$ & & & $\begin{array}{l}-\mathbf{0 . 0 6 9} * * \\
(0.034)\end{array}$ & $\begin{array}{l}-\mathbf{0 . 0 8 3} * * \\
(0.036)\end{array}$ \\
\hline RACE ISOLATION = \%(NOT MY RACE $)$ & & & $\begin{array}{l}\mathbf{0 . 0 8 1} * * * \\
(0.015)\end{array}$ & $\begin{array}{l}\mathbf{0 . 0 8 3} * * * \\
(0.016)\end{array}$ \\
\hline $\begin{array}{l}\text { AGE ISOLATION }=\mid \log (\text { AGE })- \\
\log (\text { WORKPLACE MEAN AGE }) \mid\end{array}$ & & & $\begin{array}{l}-\mathbf{0 . 2 8 8 * * *} \\
(0.013)\end{array}$ & $\begin{array}{l}-\mathbf{4 . 2 0 3 * * *} \\
(0.185)\end{array}$ \\
\hline $\operatorname{LOG}(\mathrm{AGE}) \times \operatorname{sd}(\log (\mathrm{AGE}))$ & & & & $\begin{array}{l}-\mathbf{0 . 2 0 3} \\
(0.115)\end{array}$ \\
\hline $\begin{array}{l}\log (\text { AGE }) \times \mid \log (\text { AGE })- \\
\log (\text { WORKPLACE MEAN AGE }) \mid\end{array}$ & & & & $\begin{array}{l}1.275^{* * * *} \\
(0.060)\end{array}$ \\
\hline TOKEN MAN IN WORKPLACE & & & & $\begin{array}{c}\mathbf{- 0 . 0 4 1} \\
(0.030)\end{array}$ \\
\hline TOKEN WHITE IN WORKPLACE & & & & $\begin{array}{l}-\mathbf{0 . 1 7 8} \\
(0.205)\end{array}$ \\
\hline TOKEN BLACK IN WORKPLACE & & & & $\begin{array}{l}-\mathbf{0 . 0 0 1} \\
(0.016)\end{array}$ \\
\hline TOKEN ASIAN IN WORKPLACE & & & & $\begin{array}{l}-\mathbf{0 . 0 0 8} \\
(0.017)\end{array}$ \\
\hline TOKEN HISPANIC IN WORKPLACE & & & & $\begin{array}{l}\mathbf{- 0 . 0 0 9} \\
(0.019)\end{array}$ \\
\hline YOUNGEST IN WORKPLACE & & & & $\begin{array}{l}-\mathbf{0 . 0 3 9} * * * \\
(0.007)\end{array}$ \\
\hline OLDEST IN WORKPLACE & & & & $\begin{array}{c}-\mathbf{0 . 0 0 7} \\
(0.024)\end{array}$ \\
\hline R-squared & 0.04 & 0.04 & 0.04 & 0.05 \\
\hline
\end{tabular}

share is . 7 and the black share is .3, diversity is modest and turnover is modest. If the nonwhite share remains at .3 but becomes an even mixture of blacks, Asians, and Hispanics, turnover rises slightly. This increase in turnover is explained not by diversity per se, but by the main effects on AsIAN and HisPANIC, which predict above-average turnover. In Figure 2 we graph both of these alternatives.

Figure 2 uses the coefficients from Table 2, column (3) to graph the total effect of changes in racial composition combining the individual effect, the main effect (percent black, for example), the diversity effect, and the diversity effect interacted with each group (black $\times$ racial diversity, for example). Whites left more often in situations where there were fewer whites, but diversity had little effect on that result (Figure 2a). Blacks left more often when blacks were rare, and that result is slightly stronger if non-blacks were highly diverse than if they were all whites (Figure 2b). For Hispanics, unlike the other groups, turnover was lowest with a mixture of Hispanics and 
Figure 2. Predicted Turnover as a Function of the Racial Mix of Others in the Workplace.
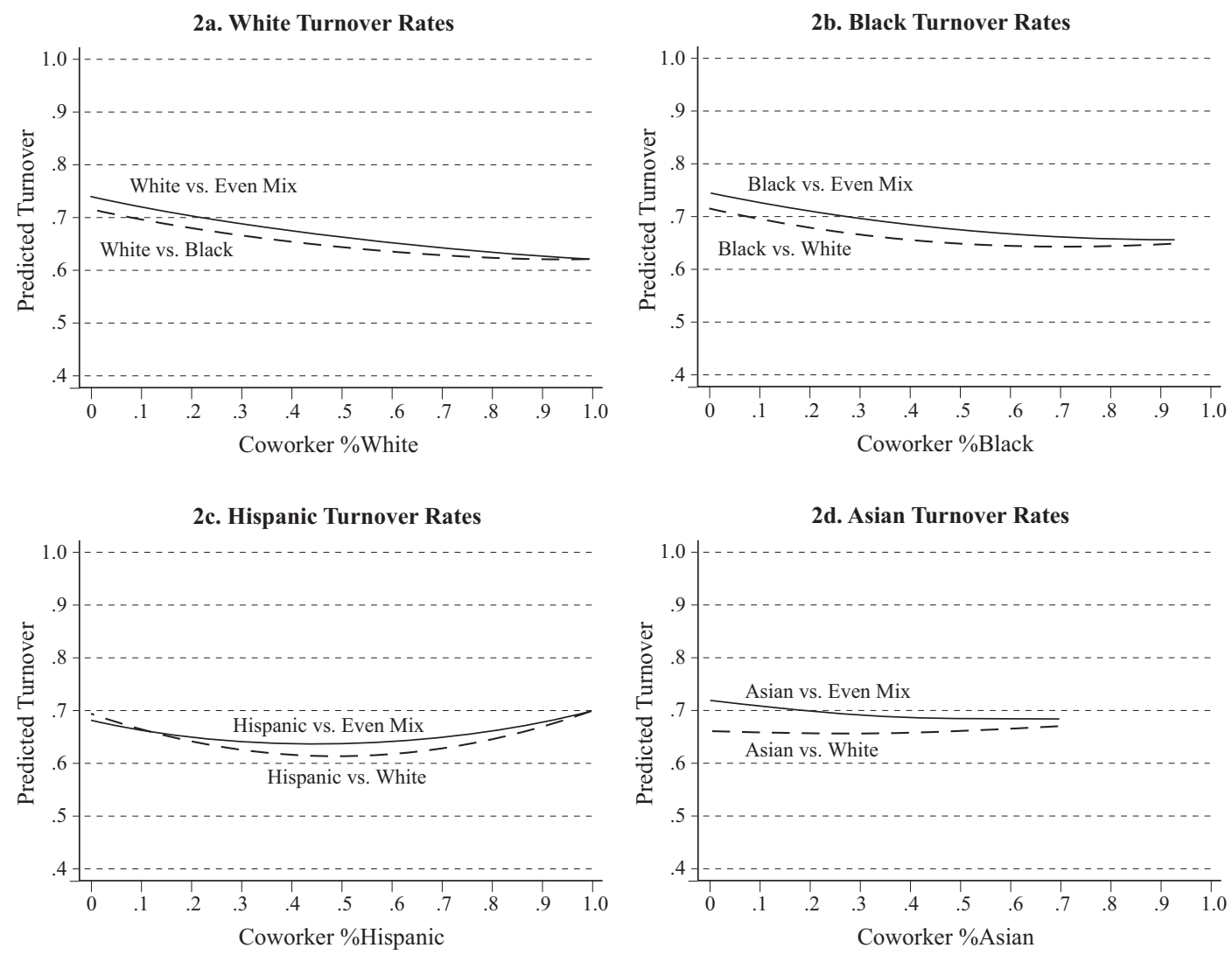

Figure 2a. The graph for White vs. Black represents the predicted turnover rate when all non-whites are black. The prediction for White vs. Even Mix assumes that non-whites are evenly distributed among blacks, Hispanics, and Asians.

Figure $2 b$. The predicted turnover rate for Black vs. Even Mix assumes that non-blacks are evenly distributed among whites, Hispanics, and Asians.

Figure 2c. The predicted turnover rate for Hispanic vs. Even Mix assumes that non-Hispanics are evenly distributed among whites, blacks, and Asians.

Figure 2d. The predicted turnover rate for Asian vs. Even Mix assumes that non-Asians are evenly distributed among whites, blacks, and Hispanics.

All figures are drawn using the coefficients from Table 2, column (3).

others (Figure 2c). Finally, Asians' turnover did not depend much on the Asian share in the workplace; at the same time, Asian turnover was lower with white colleagues than with an evenly mixed set of colleagues (Figure 2d). As is apparent, the magnitude of these effects is modest.

Age isolation had a larger effect on turnover, but it is not that predicted by Hypoth- esis 3c (that people exit when their age is far from the mean age of their workplace). The main effect on age isolation (Table 2, column 3) shows that increases in isolation reduced turnover.

This result masks some variation in the effects of age isolation, with stronger effects on younger and older employees than on those of average age (see the coeffi- 
Figure 3. Age Diversity and Turnover within Six Months.

(Based on Coefficients in Table 2, column 4)

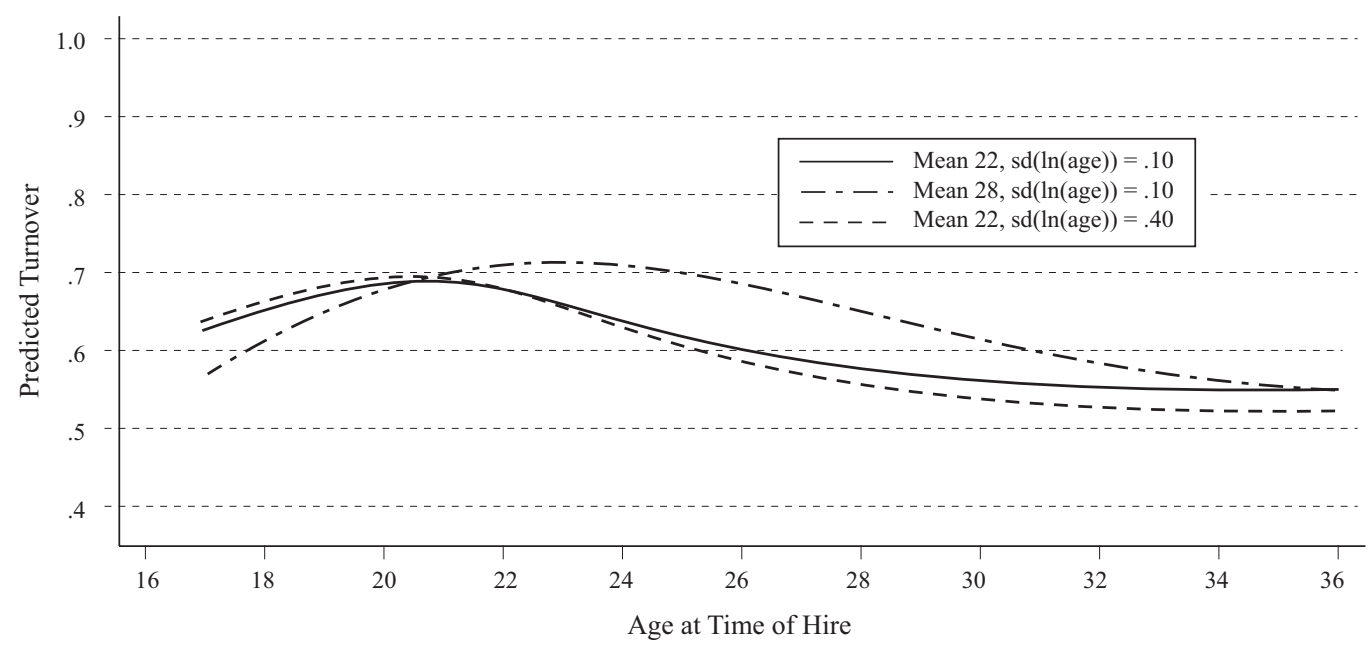

cients in Table 2, column 4, which generate Figure 3 ). When the mean age moves from 22 to 28, isolation increases for 22-year-old workers and their predicted turnover rate rises slightly from $68.5 \%$ to $70.5 \%$ (not a statistically significant change). At the same time, the same increase in mean age from 22 to 28 reduces age isolation for 28-yearold workers, but their predicted turnover rate also rises from $57.1 \%$ to $62.7 \%$. Overall we have no support for Hypothesis $4 \mathrm{~b}$ that isolation increases turnover less for high-status groups (men, whites, and older employees).

Finally, Figure 3 also shows that increasing age diversity had no effect on turnover.

\section{Extensions: Other Dimensions of Diversity}

\section{Do the Effects of Isolation Vary by Group?}

Because the specification in Table 2, column (4) examines racial isolation in general (that is, "percent not my race"), it constrains the effects of isolation on whites, blacks, Hispanics, and Asians to be equal.
Table 3 includes all the variables in the specification of Table 2, column (4), but allows racial isolation to affect each race differently. As noted above, the race isolation effect (Table 2, column 3) was .081, meaning that an increment of $10 \%$ in the number of people not of a focal employee's race led to almost $1 \%$ more turnover. Interestingly, this effect was somewhat stronger for Hispanics than for the other groups, with a coefficient on HisPanic x \% HisPanic equal to $-0.187(\mathrm{p}<.01)$; the test of difference from $-1 \times$ the overall isolation effect of 0.081 is also significant at the $1 \%$ level (Table 3, column 1). (It is not possible to estimate White x \% White due to perfect collinearity with the variables already included.)

\section{Do the Effects of Isolation Vary Depending on Who Is in the Other Groups?}

We next turn to the hypotheses that the detailed racial composition of coworkers not of one's own race matters (Hypotheses 5a-c). Are all coworkers not of one's own race lumped together in terms of their effect on turnover? Column (2) of Table 3 
Table 3. Interaction Coefficients for Each Race and the Proportion of Each Other Race in the Store. (Linear Fixed Effects Regressions Predicting Turnover within 6 Months)

\begin{tabular}{|c|c|c|}
\hline Independent Variable & $\begin{array}{l}\text { Model } 1 \\
\text { ing (Race) } \times(\% \text { Other Race }) \\
\text { Same for All Other Races }\end{array}$ & $\begin{array}{c}\text { Model } 2 \\
\text { Full Set of } \\
(\text { Race }) \times(\text { Other Race })\end{array}$ \\
\hline BLACK & $\begin{array}{l}0.065^{* * *} \\
(0.007)\end{array}$ & $\begin{array}{l}-0.085 * * * \\
(0.024)\end{array}$ \\
\hline HISPANIC & $\begin{array}{c}-0.012 \\
(0.009)\end{array}$ & $\begin{array}{l}-0.125 * * * \\
(0.048)\end{array}$ \\
\hline ASIAN & $\begin{array}{l}-0.00007 \\
(0.008)\end{array}$ & $\begin{array}{l}-0.210 * * * \\
(0.029)\end{array}$ \\
\hline WORKPLACE \%BLACK & $\begin{array}{c}0.073 \\
(0.052)\end{array}$ & $\begin{array}{l}0.122 * * \\
(0.053)\end{array}$ \\
\hline WORKPLACE \%HISPANIC & $\begin{array}{l}0.165 * * \\
(0.069)\end{array}$ & $\begin{array}{l}0.185^{* * *} \\
(0.070)\end{array}$ \\
\hline WORKPLACE \%ASIAN & $\begin{array}{l}0.149 * * \\
(0.061)\end{array}$ & $\begin{array}{l}0.211 * * * \\
(0.062)\end{array}$ \\
\hline BLACK $\times \%$ NOT BLACK & $\begin{array}{l}0.131 * * * \\
(0.027)\end{array}$ & \\
\hline BLACK $\times \%$ WHITE & & $\begin{array}{l}0.171 * * * \\
(0.029)\end{array}$ \\
\hline BLACK $\times \%$ HISPANIC & & $\begin{array}{l}-0.035 \\
(0.047)\end{array}$ \\
\hline BLACK $\times \%$ ASIAN & & $\begin{array}{l}0.226 * * * \\
(0.058)\end{array}$ \\
\hline $\begin{array}{l}\text { F-Test for Whether the Three Coefficients above Differ from } \\
\text { the Coefficient on Black } \times \% \text { Not Black from Model } 1\end{array}$ & & $\begin{array}{l}17.92 \\
(0.000)\end{array}$ \\
\hline HISPANIC $\times \%$ NOT HISPANIC & $\begin{array}{l}0.187 * * * \\
(0.032)\end{array}$ & \\
\hline HISPANIC $\times \%$ WHITE & & $\begin{array}{l}0.251 * * * \\
(0.034)\end{array}$ \\
\hline HISPANIC $\times \%$ BLACK & & $\begin{array}{c}0.061 \\
(0.052)\end{array}$ \\
\hline HISPANIC $\times \%$ ASIAN & & $\begin{array}{l}0.149 * * \\
(0.066)\end{array}$ \\
\hline $\begin{array}{l}\text { F-Test for Whether the Three Coefficients above Differ from } \\
\text { the Coefficient on Hispanic } \times \% \text { Not Hispanic from Model } 1\end{array}$ & & $\begin{array}{l}13.87 \\
(0.000)\end{array}$ \\
\hline ASIAN $\times \%$ NOT ASIAN & $\begin{array}{l}0.116^{* *} \\
(0.052)\end{array}$ & \\
\hline ASIAN $\times \%$ WHITE & & $\begin{array}{l}0.144 * * * \\
(0.055)\end{array}$ \\
\hline ASIAN $\times \%$ BLACK & & $\begin{array}{l}-0.023 \\
(0.066)\end{array}$ \\
\hline ASIAN $\times \%$ HISPANIC & & $\begin{array}{c}0.059 \\
(0.076)\end{array}$ \\
\hline $\begin{array}{l}\text { F-Test for Whether the Three Coefficients above Differ from } \\
\text { the Coefficient on Asian } \times \% \text { NOT ASIAN from Model } 1\end{array}$ & & $\begin{array}{l}9.20 \\
(0.000)\end{array}$ \\
\hline
\end{tabular}

Notes: Standard errors in parentheses. Regressions include all of the controls in Table 2, column (4). The F test examines whether the effects of employees not of this person's race differ among the three other races. It tests model 1 versus model 2 for each race; that is, can we constrain the three coefficients in each row of model 2 to equal the coefficient in the first column? The F statistics have degrees of freedom $(2,>70,000)$. The sample drops Native Americans and Unknowns.

**Statistically significant at the .05 level; ***at the .01 level. 
allows each race to affect each other race differently.

Black exits were particularly rapid when coworkers were white or Asian, with effects roughly twice as large as the average isolation effect (and difference $\mathrm{p}<.01$ ). In contrast, Hispanic colleagues did not increase black employees' exit rate. Similarly, Hispanics left stores with many whites or Asians, but were not statistically significantly more likely to leave stores with coworkers who were black. Asians left more often when coworkers were white, but were not significantly affected by black or Hispanic co-workers. An F-test strongly rejects the hypothesis that white, black, and Hispanic coworker effects on Asians were the same. It is not possible to examine which groups led to white exits, due to perfect collinearity with the variables already included. There is evidence that blacks preferred Hispanic to white coworkers (supporting Hypothesis 5b), and that Hispanics preferred black to white coworkers (supporting Hypothesis 5c). Asians left due to the presence of whites. We can also read the table emphasizing the effects of workplace average demographics. Both Hispanics and blacks were more likely to leave workplaces with more Asians. All of the minority groups, blacks, Hispanics, and Asians, were more likely to quit whiter workplaces. In this sense, our results suggest that diversity is difficult to sustain.

\section{Tokens}

Tokens are (by definition) maximally distinct from the rest of the workplace. If increasing isolation has increasing costs for the isolated individuals, theories of isolation and relational demography predict the highest turnover for tokens. Theories of norms suggest that white, male, and oldest tokens may not experience all the negative effects that female, racial minority, and youngest tokens do.

Inspection of the nonparametric graphs (Figures 1, 2, and 3) does not show any dramatic increase of exit rates when the share of same-race or same-sex colleagues moves toward zero. In Table 2 the effects on turnover of being a token are presented in column (4). No race or gender tokens had statistically significant distinctive quit rates. (We were unable to estimate the coefficient for token female, however, because too few workplaces had only one woman.) The age extremes are less visibly tokens than are the lone blacks and lone men. Nevertheless, the youngest had below-average turnover.

These results provide no evidence that being a token-the extreme of isolationpredicts low retention (contrary to Hypothesis 6a). For high-status groups (men and whites), we stated offsetting predictions of lower turnover due to higher status (Hypothesis $6 \mathrm{~b}$ ) and higher turnover due to unfamiliarity with being a token (Hypothesis 6b'). Our results do not suggest that either of these effects dominates, although it is possible that each has considerable influence and that the two are mutually offsetting.

At the same time, this setting is a difficult one in which to study token status. We measure token status at the date of hire; it is likely that in many cases a token did not remain the only person of his or her group for very long. At an extreme in the demographic distribution, tokens tend to be transient. Additionally, most of the employees in these stores work rotating part-time shifts, with the result that isolation is apt to be effectively increased. For example, if two men are working in a store with thirty women, during most of their shifts each man will probably be the only male working in the store. As we do not have shift-level data, we cannot measure the share of time a person was the only representative of a demographic group.

\section{Isolation along Multiple Dimensions}

Given the relatively consistent effects of race and gender isolation described above, it is interesting to look at the effects of isolation along multiple dimensions ( $\mathrm{Hy}-$ pothesis 7). In fact, race and gender isolation do show a negative interaction, as predicted by Hypothesis 7. A ten percentage point increase in the share of white women 
(the most common gender $\mathrm{x}$ race group) at a workplace reduced a white woman's turnover by about half of a percentage point (Appendix, column 1). This effect is beyond the effects of increasing the proportion white and the proportion female. This result is not only found among white women.

If we rerun the analysis with a variable measuring the proportion of the work force sharing each worker's race and gender, the estimated effect is roughly the same size (Appendix, column 2).

\section{Isolation from Customers}

Our next tests examine the effects of isolation from customers. For three of the four racial groups, higher shares of the same race or ethnicity in the community were associated with lower turnover (Table 4). The effects are statistically significant for blacks and Hispanics, but not for whites. For Asians the effect is weakly positive, but it is not statistically significant. Thus the results partially support Hypothesis 8 that isolation from potential customers increases exits: black and Hispanic employees were less likely to quit in heavily black and Hispanic communities, respectively.

The results for blacks indicate that the presence in the community of 10 percentage points more blacks reduced black turnover in the first six months by almost 1 percentage point. The effect is about half again larger for Hispanics. In an organization with almost two-thirds of workers exiting within 6 months, the effects for both groups are economically rather small. Recall that these results incorporate a fixed effect for each workplace; thus, they are not due to different labor markets that blacks and whites are typically located in.

It is reasonable to wonder whether these results reflect more than just black and Hispanic employees' comfort around similar customers. Minority employees have to travel further to jobs in communities with few minorities. Whites were almost twice as likely as blacks $(14 \%$, versus $7.6 \%)$ to live in the same ZIP code as their workplace. Rates for Hispanics (10\%) and Asians (11\%) were intermediate. It is possible, then, that minorities had more dismissals due to lateness and absences (the main causes for dismissals at this employer).

In fact, however, the effects of living near the workplace do not appear to drive our results. Living in the same ZIP code as the workplace had no effect on turnover rates. Controlling for whether an employee's place of residence and workplace had the same ZIP code, as well as for an interaction of that measure and race, had no effect on how the community percent black and percent Hispanic affected turnover rates of blacks and Hispanics. (Results are available on request.)

\section{Robustness Checks}

Local labor market shocks might affect both workplace demographics and exit rates. For example, if labor markets tighten more rapidly in one region than across the nation as a whole, the employer might hire less-advantaged groups, and turnover rates will rise. If racial minorities are over-represented among the disadvantaged, such labor market tightening will make it appear that rising minority shares increase turnover.

To control for this possibility, we permitted each of our local labor markets (defined by the first four digits of a ZIP code) to have a location-specific trend in turnover rates. In results not shown, permitting several hundred local trends had no important effect on the results.

As noted above, we replaced the logits on six-month retention with Cox proportional hazard rate models that permit the equivalent of workplace fixed effects. Again, results were very similar to those presented in the tables.

Because it may sometimes be difficult to separate dismissals from quits, our analysis treats all separations as the same. At the same time, our theories largely address voluntary exits. We replicated our analysis using quits as identified in an exit interview as the dependent variable. Whether all exits or only those coded as quits are included, our major conclusions are the same. In fact, it is possible that some exits re- 
ported as "quits" were, in fact, involuntary-induced by the threat of being fired, for example-but this appears to be of little consequence for our work. The results of the analysis are not substantively affected by whether we look at all turnover or only at explicitly labeled quits.

\section{Discussion}

\section{Methodological Implications}

This study's setting holds constant a vast number of factors that plague field studies. We examine an organization that, as a matter of corporate policy, seeks to replicate the same workplace with the same practices, policies, and working conditions across almost every U.S. city and large town. Job requirements are uniformly minimal, and in nearly all cases turnover is the result of a voluntary decision to quit. In analyzing how the individual decision to quit depends on workplace demographics, this design controls for many other work conditions.

We include a workplace fixed effect that captures persistent features of the labor market-customers, regional management, and so on. Such workplace and local labor market effects, often omitted in cross-section studies, can and do bias results. Comparing the effects of percent female on female turnover with and without fixed effects demonstrates the importance of the workplace fixed effects. Moving from 50\% to $5 \%$ male coworkers reduced female turnover by over 10 percentage points in a nonparametric analysis (the largest effect size) but by only about 3 percentage points in the fixed effect regression. Omitted workplace or location characteristics are likely to confound cross-sectional studies.

Diversity is both multidimensional and complex. A key finding of this study is that results using only one or two of these many measures can give misleading results.

In most datasets, one demographic group is numerically a minority in all workgroups. For example, in studies of managers in the United States, women and nonwhites have almost always been in the minority. It is not possible with such data to convincingly dis-
Table 4. Interaction Coefficients for Each Race and the Proportion of Own Race in the Community. (Linear Regression with Workplace Fixed Effects Predicting Turnover within 6 Months)

\begin{tabular}{lc}
\hline Variable & $\begin{array}{c}\text { Coefficient } \\
(\text { Std. Error })\end{array}$ \\
\hline WHITE $\times$ COMMUNITY \%WHITE & -0.026 \\
BLACK $\times$ COMMUNITY \%BLACK & $(0.031)$ \\
HISPANIC $\times$ COMMUNITY \%HISPANIC & $-0.091^{* *}$ \\
& $(0.043)$ \\
ASIAN $\times$ COMMUNITY \%ASIAN & $(0.074)$ \\
& 0.044 \\
F $(\mathbf{4}, \mathbf{7 0 , 0 0 0})$ of 4 Interactions, & $(0.051)$ \\
above $($ Prob $>$ F) & 3.95 \\
\hline
\end{tabular}

Notes: Standard errors in parentheses. Regressions include all of the controls in Table 2, column (4). Community variables are computed from the workplace's ZIP code plus all Census tracts within 2 miles. Some workplaces are grouped for fixed effects. Community main effects on \%race are spanned by the workplace fixed effects.

**Statistically significant at the .05 level.

tinguish the main effect of reducing the minority's isolation (increasing percent minority) from the effect of increasing diversity. For example, hiring more blacks into a majority-white workplace reduces black isolation, increases white isolation, and increases diversity. When the separate effects cannot be causally identified, it is crucial that researchers describe their results appropriately; nevertheless, most researchers emphasize only one reading of their estimates.

We have also unpacked an often-used measure of diversity, the relational demography measure that indicates a focal worker's demographic distance from each coworker (Pfeffer 1983). This measure turns out to be a complicated average of diversity within the workgroup and the distance between the focal worker and the workgroup mean.

Finally, the different effects of isolation on men and on women underscore the importance of not imposing equal coefficients on different groups. 


\section{Limits on Generalizability}

Results from this organization may not generalize to other organizations, or even to all organizations within this sector. For several reasons, the effects we estimate here may be larger than in most other workplaces. First, low training, little deferred compensation, and low unemployment rates keep exit costs low. Modest effects that in other settings might lead to litigation or other methods of voicing disputes may lead to exit in this setting. Moreover, because many accessible and comparable jobs are available, turnover becomes a sensitive indicator of perceived differences across jobs. Most of these workplaces are located in shopping centers where employees have an easy time finding out about nearby job opportunities and where the costs of shifting jobs (especially during periods of tight labor markets, like the one we study) are low. In addition, the low educational requirements and modest diversity training may also contribute to larger effects here. In companies where workers are viewed as easily replaceable and expected tenure is low, employees' demographic characteristics may be more salient and influential than in companies with longer average tenure and stronger employer-employee ties, where workers have time to become better known to each other and to their employers as individuals.

In contrast, several considerations suggest that our estimates may understate the influence of demographics on turnover in most other work settings. The importance of social forces may be lower in a highturnover setting. For example, most employees are not going to be around long enough to become bitter that the promotion they were expecting went to a member of a group favored by ascribed characteristics. Moreover, these workplaces have unusually visible employee demographics because they are open to the public. Potential employees who dislike diversity can readily discover the approximate demographics of the workplace by walking in. This employee self-selection would leave only those most comfortable with diversity in diverse workplaces. It is curious, in fact, that we observe people quitting in response to something they could easily have known before starting the job. In a companion paper (Giuliano, Levine, and Leonard, 2005a) we examine how employees' likelihood of quitting is affected when a manager of their own race or gender is replaced by one of different race or gender; interestingly, we do not find that turnover among those who chose to work with a demographically different manager differed much from turnover among those who initially had a demographically similar manager.

In contrast to the workplaces examined by most previous studies of tokens, primeaged white men are a relatively small minority of the retail and food services sectors and of the employer analyzed in this paper. Thus, theories based on previous research may not apply in the present instance, because the sector we have studied does not have norms of racially homogeneous "organization men."

We are most comfortable applying our results to the low-wage service sector. ${ }^{11}$ Worklife as experienced in this sector carries implications for understanding the attitudes of the work force well beyond the $18 \%$ of the U.S. work force employed in retail and restaurants in any particular week. This sector is a common entry point into the work force. It is where many people are first socialized into workplace norms and where they will form their first direct impression of diversity in the workplace.

\section{Conclusion}

We have three main results. First, diversity does not consistently predict high turnover (contradicting Hypotheses 1 and 2). Across the seven categories (age, men, women, whites, blacks, Asians, and Hispan-

\footnotetext{
${ }^{11}$ Much previous research on diversity has concentrated on a small number of samples with accessible data: top management teams, university staffs, and (in laboratory studies) college students. Thus, the generalizability of those studies' results, as of ours, is unclear.
} 
ics), diversity increased turnover to a significant extent in only one case: women disliked gender diversity. These results provide no consistent support for ethnolinguistic fragmentation, organizational demography, or related theories. Such indifference is the hallmark of tolerance.

The second finding is that isolation, unlike diversity, is sometimes a useful predictor of retention. Consistent with theories of similarity-attraction and of relational demography, isolation by gender (at least for men) and by race predicted higher turnover (supporting Hypothesis 3a in part, and $3 \mathrm{~b}$ ). Matching the demographics of the surrounding community significantly affected black and Hispanic employees. Retention rates were higher for blacks and Hispanics who worked in communities with many residents of their race (supporting Hypothesis 8). In contrast, results on age isolation directly oppose the standard hypothesis that isolation predicts higher turnover (Hypothesis 3c). In fact, as the average age of a workplace rose over time, newly hired older workers had higher turnover.

The final main result is that gender, racial, and age tokens were not more likely to quit (contrary to Hypothesis 6); in fact, workers who were the youngest in their workplace stayed longer than similarly aged colleagues who were not the youngest in their workplace. That is, isolation may have nonlinear effects, but they do not show up as discretely higher turnover rates for the only man, black, Hispanic, or Asian or for the youngest or oldest in a workplace. It is reasonable to suspect that self-selection is at work.

While many of our results provide no support for pre-existing theories, from a policy perspective they are encouraging: most employees in this sector are not overly concerned with the age or gender composition of their workplace. At the same time, there still appears to be good reason for concern about the effects of racial isolation. Augmenting past theory, we find that racial isolation from potential customers-not just coworkers-predicts higher turnover.

Because this company attempts to clone stores, and because we control for fixed effects for each workplace, our study design controls for most factors that might affect quits. It is difficult to see what else could create the high turnover for racially isolated employees besides employee preference, which Becker defined as co-employee discrimination. We cannot unravel when the higher turnover is due to the focal employee's preference, when it is due to the workgroup's preference, and when it is due to both. We acknowledge that proof by residual is inherently weak (although endemic to statistical studies of employment discrimination); at the same time, it is hard to imagine a causal path other than (some) workers' preferences for colleagues of a similar race. Recognizing that people may not candidly admit they discriminate, further research that links attitudinal measures with behavioral measures of the type studied here would serve to delineate the role of preferences in explaining this relationship.

We are currently following up this study to examine how turnover and other outcomes such as hiring and promotions are affected by an employee's similarity to his or her current manager, past managers, and customers. Those results will help flesh out our understanding of this case study. Ultimately, research is needed in many sectors if we are to understand how diversity affects employees and organizations.

In the low-wage service sector where our employees work, turnover rates are so high that changes in diversity are not the main driver of turnover costs. But turnover is costly, and learning to manage a diverse work force can bring tangible benefits.

Economists' traditional prediction is that employees' preferences to work near similar others will lead to segregation (Becker 1957). In a world where complete segregation is both illegal and (given the diversity of the work force) often unsustainable for an enterprise, the problem for managers is that each new hire raises isolation for some groups at the same time that it decreases isolation for others. Managers can benefit by helping employees thrive in a world of racial diversity - a prescription that is easier to state than to implement. 


\begin{tabular}{|c|c|c|}
\hline \multicolumn{3}{|c|}{$\begin{array}{l}\text { Appendix } \\
\text { Turnover Effects of the Percentage of Coworkers Sharing a Worker's Race and Gender } \\
\text { (Linear Fixed Effects Regressions Predicting Turnover within } 6 \text { Months) }\end{array}$} \\
\hline Independent Variable & (1) & (2) \\
\hline FEMALE & $\begin{array}{l}-0.177 * * * \\
(0.046)\end{array}$ & $\begin{array}{l}-0.174 * * * \\
(0.046)\end{array}$ \\
\hline BLACK & $\begin{array}{c}-0.014 \\
(0.026)\end{array}$ & $\begin{array}{c}-0.003 \\
(0.026)\end{array}$ \\
\hline ASIAN & $\begin{array}{c}-0.070 \\
(0.038)\end{array}$ & $\begin{array}{c}-0.059 \\
(0.038)\end{array}$ \\
\hline HISPANIC & $\begin{array}{c}-0.045 \\
(0.029)\end{array}$ & $\begin{array}{c}-0.034 \\
(0.029)\end{array}$ \\
\hline WORKPLACE \%FEMALE & $\begin{array}{c}0.104 \\
(0.059)\end{array}$ & $\begin{array}{c}0.101 \\
(0.059)\end{array}$ \\
\hline WORKPLACE \%BLACK & $\begin{array}{c}0.014 \\
(0.046)\end{array}$ & $\begin{array}{l}0.025 \\
(0.046)\end{array}$ \\
\hline WORKPLACE \%ASIAN & $\begin{array}{c}0.113 \\
(0.066)\end{array}$ & $\begin{array}{c}0.123 \\
(0.066)\end{array}$ \\
\hline WORKPLACE \%HISPANIC & $\begin{array}{c}0.083 \\
(0.055)\end{array}$ & $\begin{array}{l}0.092 \\
(0.055)\end{array}$ \\
\hline $\begin{array}{l}\text { GENDER DIVERSITY INDEX }= \\
1-\left[(\% \mathrm{FEMALE})^{2}+(\% \text { MALE })^{2}\right]\end{array}$ & $\begin{array}{c}-0.132 \\
(0.084)\end{array}$ & $\begin{array}{l}-0.119 \\
(0.085)\end{array}$ \\
\hline $\begin{array}{l}\text { RACIAL DIVERSITY INDEX }=1-\left[(\% \text { WHITE })^{2}+\right. \\
\left.(\% \text { BLACK })^{2}+(\% \text { HISPANIC })^{2}+(\% \text { ASIAN })^{2}\right]\end{array}$ & $\begin{array}{c}-0.067 \\
(0.042)\end{array}$ & $\begin{array}{c}-0.066 \\
(0.042)\end{array}$ \\
\hline FEMALE $\times($ GENDER DIVERSITY INDEX $)$ & $\begin{array}{l}0.319 * * * \\
(0.082)\end{array}$ & $\begin{array}{l}0.303 * * * \\
(0.082)\end{array}$ \\
\hline BLACK $\times($ RACIAL DIVERSITY INDEX $)$ & $\begin{array}{c}0.016 \\
(0.044)\end{array}$ & $\begin{array}{c}0.014 \\
(0.044)\end{array}$ \\
\hline ASIAN $\times($ RACIAL DIVERSITY INDEX) & $\begin{array}{c}0.004 \\
(0.050)\end{array}$ & $\begin{array}{c}0.002 \\
(0.050)\end{array}$ \\
\hline HISPANIC $\times($ RACIAL DIVERSITY INDEX $)$ & $\begin{array}{c}-0.076 \\
(0.047)\end{array}$ & $\begin{array}{c}-0.079 \\
(0.047)\end{array}$ \\
\hline |FEMALE - WORKPLACE \%FEMALE| & $\begin{array}{l}-0.102 * * * \\
(0.035)\end{array}$ & $\begin{array}{l}-0.105^{* * *} \\
(0.036)\end{array}$ \\
\hline IWHITE - WORKPLACE \% WHITEI & $\begin{array}{l}0.048^{* *} \\
(0.020)\end{array}$ & $\begin{array}{l}0.044^{* *} \\
(0.020)\end{array}$ \\
\hline IBLACK - WORKPLACE \% BLACKI & $\begin{array}{c}0.028 \\
(0.016)\end{array}$ & $\begin{array}{l}0.013 \\
(0.017)\end{array}$ \\
\hline IASIAN - WORKPLACE \%ASIANI & $\begin{array}{c}0.017 \\
(0.027)\end{array}$ & $\begin{array}{c}0.002 \\
(0.027)\end{array}$ \\
\hline IHISPANIC - WORKPLACE \%HISPANICI & $\begin{array}{l}0.041 * * \\
(0.019)\end{array}$ & $\begin{array}{c}0.027 \\
(0.019)\end{array}$ \\
\hline $\mid \log (\mathrm{AGE})-\log ($ WORKPLACE MEAN AGE) $\mid$ & $\begin{array}{l}-4.211 * * * \\
(0.173)\end{array}$ & $\begin{array}{l}-4.213 * * * \\
(0.173)\end{array}$ \\
\hline (WHITE FEMALE) $\diamond$ (WORKPLACE \% WHITE WOMEN) & $\begin{array}{l}-0.045 * * * \\
(0.010)\end{array}$ & \\
\hline WORKPLACE \% SAME RACE \& GENDER AS EMPLOYEE & & $\begin{array}{l}-0.053 * * * \\
(0.015)\end{array}$ \\
\hline R-Squared & 0.05 & 0.05 \\
\hline
\end{tabular}

Notes: Other controls as in Table 2, including fixed effects for each workplace and for each starting month. Standard errors in parentheses. Sample size is $>800$ workplaces and $>70,000$ hires.

**Statistically significant at the .05 level; ***at the .01 level. 


\section{REFERENCES}

Akerlof, George A., and Rachel E. Kranton. 2000. "Economics and identity." Quarterly Journal of Economics, Vol. 115, No. 3 (August), pp. 715-53.

Alesina, Alberto, Reza Baqir, and William Easterly. 1999. "Public Goods and Ethnic Divisions." Quarterly Journal of Economics, Vol. 114, No. 4 (December), pp. 1243-84.

Alesina, Alberto, and Eliana La Ferrara. 2000. "The Determinants of Trust." NBER Working Paper No. 7621, March.

Allport, Gordon W. 1954. The Nature of Prejudice. Cambridge, Mass.: Addison-Wesley.

Ashenfelter, Orley, and Timothy Hannan. 1986. "Sex Discrimination and Product Market Competition: The Case of the Banking Industry." Quarterly Journal of Economics, Vol. 101, No. 1 (February), pp. 149-73.

Becker, Gary Stanley. 1957. The Economics of Discrimination. Chicago: University of Chicago Press.

Bernstein, Lisa. 1992. "Opting out of the Legal System-Extralegal Contractual Relations in the Diamond Industry." Journal of Legal Studies, Vol. 21, No. 1 (January), pp. 115-57.

Blau, Francine D., and Lawrence M. Kahn. 1981. "Race and Sex Differences in Quits by Young Workers." Industrial and Labor Relations Review, Vol. 34, No. 4 (July), pp. 563-77.

Boyden, Tom, John S. Carroll, and Richard A. Maier. 1984. "Similarity and Attraction in Homosexual Men: The Effects of Age and Masculinity-Femininity." Sex Roles, Vol. 10, pp. 939-48.

Byrne, Donn. 1971. The Attraction Paradigm. New York: Academic Press.

Eagly, Alice H. 1987. Sex Differences in Social Behavior: A Social Role Interpretation. Hillsdale, N.J.: Earlbaum. Easterly, William, and Ross Levine. 1997. "Africa's Growth Tragedy: Policies and Ethnic Divisions." Quarterly Journal of Economics, Vol. 112, No. 4 (December), pp. 1203-50.

Elvira, Marta, and Christopher Zatzick. 1998. "Racial Composition and Voluntary Turnover in a Multiracial Setting." Academy of Management Best Paper Proceeding.

Fairhurst, Gail Theus, and B. Kay Snavely. 1983. "Majority and Token Minority Group Relationships: Power Acquisition and Communication." Academy of Management Review, Vol. 8, No. 2 (April), pp. 292300 .

Frankenberg, Erica, Chungmei Lee, and Gary Orfield. 2003. A Multiracial Society with Segregated Schools: Are We Losing the Dream? Harvard Civil Rights Project. http://www.civilrightsproject.harvard.edu/research/reseg03/national.pdf (accessed February 22, 2005).

Glaeser, Edward L., David Laibson, and Bruce Sacerdote. 2000. "The Economic Approach to Social Capital." NBER Working Paper No. 7728 (June).

Goering, John, Judith D. Fein, and Todd M. Richardson. 2002. "A Cross-Site Analysis of the Initial Moving to Opportunity Demonstration Results." Journal of Housing Research, Vol. 13, No. 1, pp.
$1-30$.

Greif, Avner. 1993. "Contract Enforceability and Economic Institutions in Early Trade: The Maghribi Traders' Coalition." American Economic Review, Vol. 83, No. 3 (June), pp. 525-48.

Giuliano, Laura, D. I. Levine, and J. Leonard. 2005 a. "Do Race, Gender, and Age Differences Affect Manager-Employee Relations? An Analysis of Quits, Dismissals, and Promotions at a Large Retail Firm." Working Paper, University of Miami.

2005b. "Race, Gender, and Hiring Patterns: Evidence from a Large Service-Sector Employer." Working Paper, University of Miami.

Holzer, Harry J. 1988. "Search Methods Used by Unemployed Youth." Journal of Labor Economics, Vol. 6, No. 1 (January), pp. 1-12.

1996. What Employers Want: Job Prospects for LessEducated Workers. New York: Russell Sage Foundation.

Holzer, Harry J., and Keith R. Ihlanfeldt. 1998. "Customer Discrimination and Employment Outcomes for Minority Workers." Quarterly Journal of Economics, Vol. 113, No. 3 (August), pp. 835-67.

Holzer, Harry J., Steven Raphael, and Michael Stoll. 2000. "Are Suburban Firms More Likely to Discriminate against African-Americans?" Journal of Urban Economics, Vol. 48, No. 3 (November), pp. 485-508. Jehn, Karen, Greg Northcraft, and Margaret Neale. 1999. "Why Differences Make a Difference: A Field Study of Diversity, Conflict, and Performance in Workgroups." Administrative Science Quarterly, Vol. 44, No. 4 (December), pp. 741-63.

Kanter, Rosabeth Moss. 1977. Men and Women of the Corporation. New York: Basic Books.

Lang, Kevin. 1986. "A Language Theory of Discrimination." Quarterly Journal of Economics, Vol. 101, No. 2 (May), pp. 363-82.

Massey, Douglas S., and Nancy A. Denton. 1993. American Apartheid: Segregation and the Making of the Underclass. Cambridge, Mass.: Harvard University Press.

Neumark, David, Roy J. Bank, and Kyle D. Van Nort. 1996. "Sex Discrimination in Restaurant Hiring: An Audit Study." Quarterly Journal of Economics, Vol. 111, No. 3 (August), pp. 915-41.

O'Reilly III, Charles A., David F. Caldwell, and William P. Barnett. 1989. "Work Group Demography, Social Integration, and Turnover." Administrative Science Quarterly, Vol. 34, No. 1 (March), pp. 21-37.

Pelled, Lisa Hope. 1996. "Demographic Diversity, Conflict, and Work Group Outcomes: An Intervening Process Theory." Organization Science, Vol. 7, No. 6, pp. 615-31.

Pfeffer, Jeffrey. 1983. "Organizational Demography." In Barry Staw and Larry L. Cummings, eds., Research in Organizational Behavior, Vol. 5. Greenwich, Conn.: JAI Press.

Price, James L., and Charles W. Mueller. 1981. Professional Turnover: The Case of Nurses. Jamaica, N.Y.: Spectrum.

Reskin, Barbara F., Debra B. McBrier, and Julie A. 
Kmec. 1999. "The Determinants and Consequences of Workplace Sex and Race Composition." Annual Review of Sociology, Vol. 25, pp. 335-61.

Riordan, Christine M., and Lynn McFarlane Shore. 1997. "Demographic Diversity and Employee Attitudes: An Empirical Examination of Relational Demography within Work Units." Journal of Applied Psychology, Vol. 82, No. 3 (June), pp. 342-58.

Sacco, Joshua M., and Neal Schmitt. 2005. "A Dynamic Multilevel Model of Demographic Diversity and Misfit Effects." Journal of Applied Psychology, Vol. 90, No. 2 (March), pp. 203-31.

Senn, D. J. 1971. "Attraction as a Function of Similarity-Dissimilarity in Task Performance." Journal of Personality and Social Psychology, Vol. 18, No. 1 (February), pp. 12-123.

Stata. 2005. Stata Reference Manual: Release 9. Plano, Tx Tajfel, Henri, and John C. Turner. 1986. "The Social Identity Theory of Intergroup Behavior." In S. Worschel and W. G. Austin, eds., Psychology of Intergroup Relations, 2nd ed. Chicago: Nelson-Hall, pp. $7-24$.

Tannen, Deborah. 1990. You Just Don't Understand: Women and Men in Conversation, 1st ed. New York: Morrow.

Tiebout, Charles M. 1956. "A Pure Theory of Local Government Expenditures." Journal of Political Economy, Vol. 64, No. 5 (October), pp. 416-24.

Tsui, Anne S., Terri D. Egan, and Charles A. O'Reilly
III. 1992. "Being Different: Relational Demography and Organizational Attachment." Administrative Science Quarterly, Vol. 37, pp. 549-79.

Tsui, Anne S., and Charles A. O'Reilly III. 1989. "Beyond Simple Demographic Effects: The Importance of Relational Demography in Superior-Subordinate Dyads." Academy of Management Journal, Vol. 32, No. 2 (June), pp. 402-23.

Turner, John C. 1985. "Social Categorization and the Self-Concept: A Social Cognitive Theory of Group Behavior." In Edward J. Lawler, ed., Advances in Group Processes: Theory and Research, Vol. 2. Greenwich, Conn.: JAI Press, pp. 77-121.

Wiersema, Margarethe F., and Allan Bird. 1993. "Organizational Demography in Japanese Firms: Group Heterogeneity, Individual Dissimilarity, and Top Management Team Turnover." Academy of Management Journal, Vol. 36, No. 5 (October), pp. 996-1025.

Williams, K. Y., and Charles A. O'Reilly. 1998. "Forty Years of Diversity Research: A Review." In Margaret A. Neale, Elizabeth A. Mannix, and Deborah H. Gruenfeld, eds., Research on Managing Groups and Teams. Greenwich, Conn.: JAI Press.

Wong, Paul, Chienping Faith Lai, Richard Nagasawa, and Tieming Lin. 1998. "Asian Americans as a Model Minority: Self-Perceptions and Perceptions by Other Racial Groups." Sociological Perspectives, Vol. 41, No. 1, pp. 95-118. 